\title{
Biodegradation of Oil Refinery Residues Using Mixed- Culture of Microorganisms Isolated from a Landfarming
}

\author{
Eduardo Beraldo de Morais* and Sâmia Maria Tauk-Tornisielo \\ Centro de Estudos Ambientais; Universidade Estadual Paulista; Av. 24-A, 1515; 13506-900; Rio Claro - SP - Brasil
}

\begin{abstract}
In this study, the potential for using an inoculum composed of a mixed-culture of bacteria and fungi, isolated from a landfarming at the Paulinia Oil Refinery, Brazil, to degrade oil residues generated in the process of petroleum refinement was investigated. The isolation of these microorganisms was carried out beforehand, assuming that they would be better adapted to petroleum hydrocarbons, as the landfarming consisted of an area impacted by the deposit of such compounds. The Bartha and Pramer respirometric test was used to measure the rate of biodegradation of the hydrocarbons by the mixed-culture of microorganisms via the evolution of $\mathrm{CO}_{2}$. The results obtained with respect to the efficiency of biodegradation showed no significant differences $(P>0.05)$, indicating no increase in the biodegradation process using the inoculum. The addition of nutrients $(N, P, K)$ also did not contribute to an increase in biodegradation of the oil residue studied.
\end{abstract}

Key words: biodegradation, oil residue, petroleum, inoculum, mixed-culture

\section{INTRODUCTION}

The effectiveness of microorganisms as agents in the destruction and recycling of organic matter in the biosphere is widely acknowledged (Régis and Bidoia, 2005). Microorganisms are considered to be efficient biodegraders due to their abundance, the wide variety of species, and their catabolic and anabolic versatility, as well as their ability to adapt to adverse environmental conditions. Through the metabolic activity of these microorganisms, organic pollutants can be transformed into water, $\mathrm{CO}_{2}$ and biomass (Genow et al., 1994).

The appropriate disposal of residues generated in different industrial processes has been of great concern because of the speed and intensity of the environmental damage they can provoke. Oil residues, or oil sludge, resulting from industrial processes in oil refineries can pollute the environment, representing a danger to all forms of life when not disposed appropriately. Strategies for controlling environmental contamination by petroleum and its derivatives have been the subject of various studies over the past three decades (Miranda et al., 2007).

The biodegradation of petroleum hydrocarbons by natural populations of microorganisms represents one of the primary mechanisms through which these polluting compounds can be eliminated from the environment (Rosato, 1997). Oil sludge is composed mainly of oil, water, and particulate matter and is extremely difficult to re-use due to its characteristics (Ururahy et al., 1998). One of the alternatives for treating this residue to mitigate

*Author for correspondence: beraldo_morais@yahoo.com.br 
the negative environmental impact associated with its disposal is biodegradation using microorganisms.

The biodegradation of oil residues requires a complex metabolic pathway which is not always found in a single species of microorganisms but which can be observed in a microbial community. Many studies have been carried out on the biodegradation of petroleum hydrocarbons using a consortium of microorganisms (Jørgensen et al., 2000; Li et al., 2000; Del' Arco and França, 2001; Vasudevan and Rajaram, 2001; Mrayyan and Battikhi, 2005). In a mixed-culture, the metabolic products of one species can be degraded by another present in the culture, and so on successively, leading to complete degradation of the substrate despite the lack of a specific type of microorganism in the community capable of degrading it alone (Kataoka, 2001).

The microbial species that degrade hydrocarbons are widely distributed in nature and are not restricted to only a few genera. Some of the various genera of bacteria capable of degrading hydrocarbons include: Pseudomonas, Brevundimonas, Sphingomonas, Acinetobacter, Rhodococcus, Arthrobacter, Corynebacterium, Bacillus, Ochrobactrum, Stenotrophomonas, Burkholderia, Xanthomonas, and Hyphomicrobium (Chaîneau et al., 1999; Li et al., 2000; Chaerun et al., 2004; Yoshida et al., 2006) and the fungi Aspergillus, Penicillium, Beauveria, Acremonium, Cladosporium, Fusarium, Trichoderma, Amorphoteca, Neosartorya, Paecilomyces, Talaromyces and Graphium, among others (Chaîneau et al., 1999; Chaillan et al., 2004).

In addition to using microorganisms with the metabolic systems needed to biodegrade and remove petroleum residues from the environment, the microbial community can also be stimulated by adding nitrogen and phosphorous, preventing the absence of nutrients from becoming a limiting factor in biodegradation. Hydrocarbons are composed mainly of carbon and hydrogen and generally occur in proportions of $\mathrm{C}: \mathrm{N}: \mathrm{P}$ that are not optimal for maximum microbial activity. Studies conducted by Ayotamuno et al. (2006) showed that the use of agricultural fertilizers (NPK) increased the total number of heterotrophic bacteria, accelerating the biodegradation of petroleum hydrocarbons in the soil.
Biodegradation reached $95 \%$ of the hydrocarbons, whereas biodegradation of hydrocarbons in the control soil, which received no nutrients, was apparently unaltered.

The complete degradation of a compound to its mineral components, in which the organic carbon of the compound is converted to $\mathrm{CO}_{2}$ by respiration, is called mineralization. When the aerobic conditions are maintained, $\mathrm{CO}_{2}$ evolution can be used as a measure of microbial metabolic activity with reasonable accuracy (Atlas, 1992). Studies involving the measurement of the rate of mineralization can provide important information about the biodegradability of industrial waste compounds, including oil residues.

Various methods can be used to measure the rates of carbon dioxide production, such as the respirometric flask. This methodology has been proven effective for establishing the best protocols to follow during the biodegradation of residues as it provides rapid results, making it possible to test various options, such as the addition of nutrients and microorganisms (Balba et al., 1998).

In this study, the capacity of a mixed-culture inoculum of microorganisms to increase the biodegradation of oil residues produced in the process of petroleum refinement was tested. Also, the effect of the addition of nutrients, including nitrogen, phosphorus and potassium, with respect to an increase in the rate of biodegradation of residue, was studied.

\section{MATERIAL AND METHODS}

\section{Oil Residue}

The oil residue studied was collected from the bottom of storage tanks and from discharge treatment units at the Paulínia Oil Refinery (REPLAN), in the city of Paulínia, São Paulo, Brazil. Characteristics of the oil sludge are presented in Table 1.

\section{Soil}

The soil used for the biodegradation assay of the oil residue was collected from a depth of $0-50 \mathrm{~cm}$ in the "Navarro de Andrade" State Forest, Rio Claro, São Paulo, following Technical Norm L6.245 (Cetesb, 1984). Analysis of its chemical and physical characteristics indicated it had a clay texture (Table 2). 
Table 1 - Oil sludge characteristics.

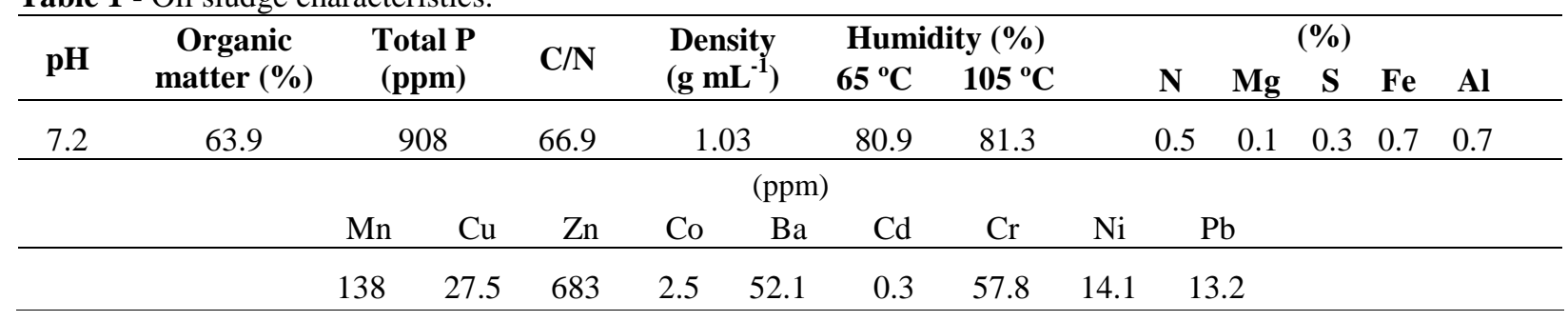

Table 2 - Chemical and physical characteristics of the soil used for the biodegradation assay of the oil residue.

\begin{tabular}{|c|c|c|c|c|c|c|c|c|c|c|c|c|}
\hline pH & Organic & Total N & Total P & & Micr & onutr & ients & (mg kg & & Sand & Clay & Silt \\
\hline (water) & carbon $\left(\mathrm{g} \mathrm{kg}^{-1}\right)$ & $(\%)$ & $\left(\mathrm{mg} \mathrm{kg}^{-1}\right)$ & $\left(\mathrm{mmol} \mathrm{kg}^{-1}\right)$ & $\mathbf{F e}$ & Mn & $\mathrm{Cu}$ & B & Zn & & $(\%)$ & \\
\hline 5.8 & 13.0 & 0.1 & 3.0 & 43.4 & 4.0 & 4.5 & 0.8 & 0.14 & 0.2 & 41.2 & 54.4 & 4.4 \\
\hline
\end{tabular}

\section{Preparation of the Mixed-culture Inoculum}

The microorganisms used to elaborate the mixedculture inoculum were isolated from an area impacted by petroleum hydrocarbons, the REPLAN landfarming, and later identified (Kataoka, 2001). The microorganisms consisted of seven strains of fungi (Trichoderma pseudokoningii, Eurotium amstelodami, Aspergillus flavus, Pseudallescheria boydii, Aspergillus versicollor, Aspergillus terreus and Cylindrocarpon didymum) and four strains of bacteria (Ochrobactrum anthropi, Stenotrophomonas maltophilia, Bacillus cereus, plus one strain unidentified by traditional taxonomic standards).

The bacterial strains were grown on Plate Count Agar (PCA) culture medium (5.0 g of tryptone; 2.5 $\mathrm{g}$ of yeast extract; $5.0 \mathrm{~g}$ of glucose; $15.0 \mathrm{~g}$ of agar and $1000 \mathrm{~mL}$ of distilled water) at $36^{\circ} \mathrm{C}$ for three days. Aqueous suspensions were then made of each culture, standardizing them to the number 8 tube on the MacFarland scale. The tube 8 represented the turbidity of bacteria at a concentration of $2.4 \times 10^{9} \mathrm{~mL}^{-1}$ (Bier, 1994). The fungi strains were inoculated on malt extract culture medium $(20.0 \mathrm{~g}$ of malt extract; $1.0 \mathrm{~g}$ of peptone; $20.0 \mathrm{~g}$ of glucose; $20.0 \mathrm{~g}$ of agar and $1000 \mathrm{~mL}$ of distilled water) at $30{ }^{\circ} \mathrm{C}$ for seven days. Suspensions were then made and standardized by counting spores in a Neubauer chamber containing $10^{7}$ spores $\mathrm{mL}^{-1}$. For the biodegradation assays of the oily residue, the bacterial strains were added in a proportion of approximately $9.6 \times 10^{7}$ cells $\mathrm{g}^{-1}$ of dry soil while the fungi spores were added in a proportion of $4 \mathrm{x}$ $10^{5}$ spores $\mathrm{g}^{-1}$ of dry soil.

\section{Biodegradation Assay of the Oil Residue}

The biodegradation assay of the oil residue was carried out according to Technical Norm L6.350 (Cetesb, 1990). The Bartha and Pramer respirometer is composed of a closed system containing two connected chambers where the biodegradation process and removal of $\mathrm{CO}_{2}$ take place (Fig. 1). To carry out the biodegradation assays of the oil residue, the field capacity of the soil collected was determined according to the recommendations in Norm L6.350 (Cetesb, 1990). The soil was mixed with the oil residue in a proportion of $5 \%\left(\mathrm{w} \mathrm{w}^{-1}\right)$, after correcting the moisture level to $70 \%$ of the field capacity. Following the homogenization of the mixture, $50 \mathrm{~g}$ were added to each respirometer.

Four treatments were carried out in triplicate: 1) control containing only $50 \mathrm{~g}$ of soil; 2) $50 \mathrm{~g}$ of soil/oil residue mixture, also considered as control; 3) $50 \mathrm{~g}$ of soil/oil residue mixture plus mixedculture inoculum; and 4) $50 \mathrm{~g}$ of soil/oil residue mixture plus mixed-culture inoculum and a quantity of fertilizer commonly used for plants (to achieve a $\mathrm{C}: \mathrm{N}$ ratio of $30: 1)$. The respirometers were incubated at $28 \pm 1{ }^{\circ} \mathrm{C}$ for 133 days.

The $\mathrm{CO}_{2}$ produced was trapped in a $10.0 \mathrm{~mL}$ solution of $\mathrm{KOH}(0.2 \mathrm{~N})$, located in the side-arm of the respirometer. This solution was periodically substituted for another containing no $\mathrm{CO}_{2}$ to avoid saturation with the gas. Quantification of the $\mathrm{CO}_{2}$ was done through titration of $\mathrm{KOH}$ removed from the respirometer, after the addition of $1 \mathrm{~mL}$ of barium chloride solution $(1.0 \mathrm{~N})$ used to precipitate the carbonate ions and two drops of phenolphthalein, with a standard solution of $\mathrm{HCl}$ $(0.1 \mathrm{~N})$. 


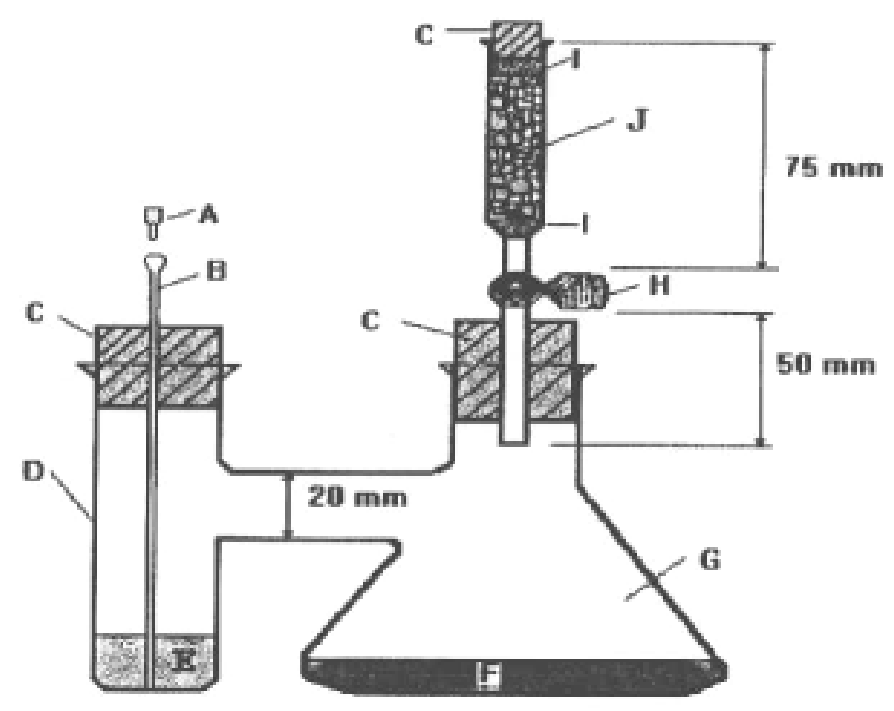

Figure 1 - Model of the system used for the Respirometer. A - Cover of the cannula; B - Cannula; C - Tightly closed rubber cork; D - Lateral arm; E - KOH solution; F - Sample of the soil/residue mixture to be degraded; G - $300 \mathrm{~mL}$ flask; H - Valve; I - Supported layer (glass wool); $\mathrm{J}-\mathrm{CO}_{2}$ Filter

\section{Biodegradation efficiency calculation}

The carbon dioxide analyses were used to estimate the total amount of hydrocarbons mineralized during biodegradation experiments. According to the Norm L6.350 (Cetesb, 1990), 50\% of the biodegraded carbon is converted to $\mathrm{CO}_{2}$ and the other $50 \%$ is added to the soil as humus and biomass, and the total biodegraded carbon may be calculated using equation I.

Total biodegraded carbon $=2 \times \mathrm{CO}_{2}$ produced

Thus, the biodegradation efficiency (BE \%) may be calculated by equation II.

$$
\mathrm{BE}(\%)=\frac{\text { Total biodegraded carbon }}{\text { Initial soil organic carbon content }} \times 100
$$

\section{RESULTS AND DISCUSSION}

\section{Evolution of $\mathrm{CO}_{2}$ Production}

Fig. 2 presents the results of the evolution of $\mathrm{CO}_{2}$ production during 133 days of biodegradation of the oil residue in the different types of treatments used. The values with respect to $\mathrm{CO}_{2}$ produced in the control treatment containing soil/residue mixture were greater than the treatment containing soil only, also considered to be a control. These results indicated that microorganisms present in the soil could increase the rate of biodegradation of the oil residue or it might activate the microbial metabolism of the soil used in this study.

The results showed that, in the treatment containing soil/oil residue mixture inoculated with mixed-culture and fertilizer, the greatest $\mathrm{CO}_{2}$ production occurred in the first 14 days of incubation. The addition of fertilizer together with the inoculum probably favored greater microbial activity under the conditions present in the respirometer in the first days of the assays. Nevertheless, after two weeks, $\mathrm{CO}_{2}$ emission in this system was not greater in relation to the other treatments, which indicated rapid consumption of nutrients and a consequent decrease in microbial activity. Between day 21 and day 37 of the experiment, the control treatment containing soil/oil residue mixture presented greater $\mathrm{CO}_{2}$ evolution in relation to the other treatments, indicating the potential of the microbial community in the soil and in the residue to biodegrade some compounds present in the latter. 


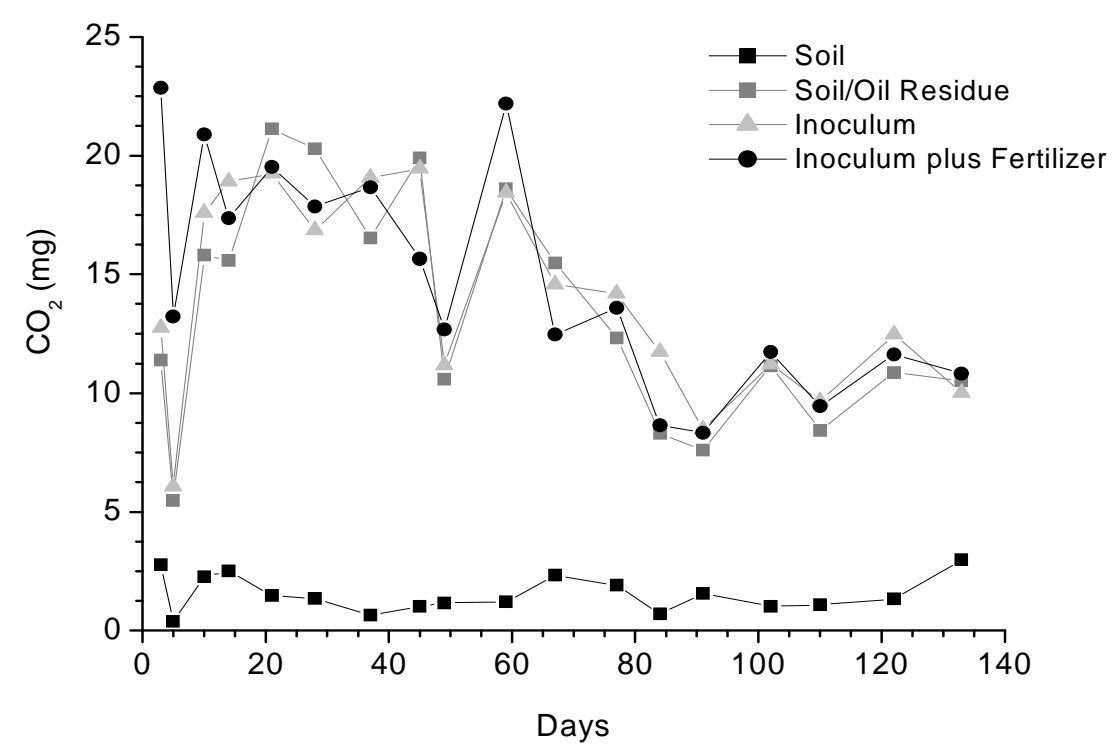

Figure 2 - Evolution of $\mathrm{CO}_{2}$ produced during biodegradation assay of oil residue during 133 days.

$\mathrm{CO}_{2}$ Accumulated During the Biodegradation Assay of the Oil Residue

The findings regarding the quantity of $\mathrm{CO}_{2}$ accumulated during the biodegradation assay in the different treatments (Fig. 3) showed that the use of the inoculum, and of the inoculum together with fertilizer, resulted in an increase of $1.8 \%$ and $5.3 \%$, respectively, in the production of $\mathrm{CO}_{2}$ compared to the mixed soil/oil residue control.

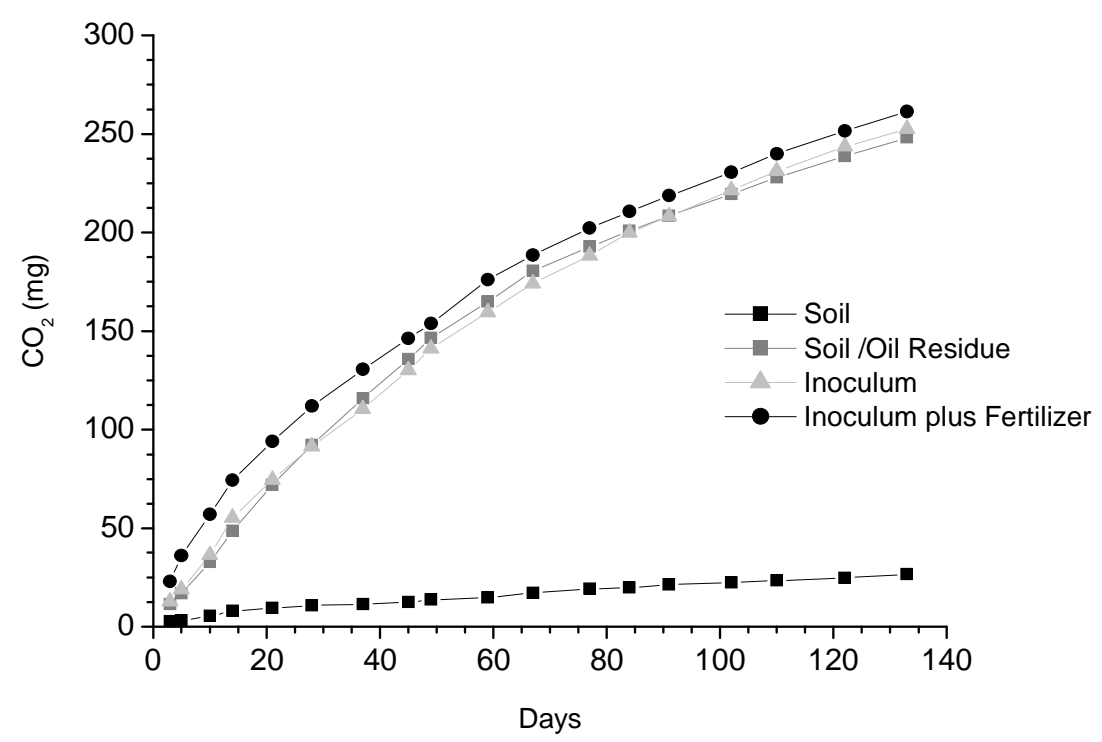

Figure 3 - Cumulative total amounts of $\mathrm{CO}_{2}$ produced during the biodegradation assay of the oil residue. 
More than $50 \%$ of the total $\mathrm{CO}_{2}$ accumulated in the treatments was produced in the first 45 days, probably due to the more rapid consumption of those compounds that were more easily biodegraded by the microorganisms, e.g. linear and open-chain hydrocarbons. Those recalcitrant compounds that were more resistance to degradation were consumed more slowly later or might not have been consumed. Similar findings were reported by Margesin et al. (2000) in a study of biodegradation of diesel fuel, in which a large part of the $\mathrm{CO}_{2}$ production occurred in the first 15 days, followed by a decrease in its production.

In studies conducted with different fractions of hydrocarbons present in oil residues from petroleum refinement, a reduction in saturated and aromatic compounds of 70 and $60 \%$, respectively, was observed. Next, a $30 \%$ reduction in resins occurred. The asphaltenes, however, remained constant, without undergoing biodegradation (Capelli et al., 2001). These compounds are longchained, inhibiting their biodegradation, although the low rate of biodegradation of the pollutant can also be attributed to physical factors such as adsorption of the contaminant to the soil particles, or their strong link to organic substances in the soil. Other authors have reported that some petroleum fractions and their derivatives were rarely biodegraded and that the stabilization of the concentrations of these fractions in the soil, called residual concentration, could occur (Nocentini et al., 2000).

\section{Efficiency of biodegradation}

Based on the $\mathrm{CO}_{2}$ production, the biodegradation efficiency of oil residue was calculated for each treatment using the initial carbon levels in the soil/oil residue mixture $\left(34 \mathrm{~g} \mathrm{~kg}^{-1}\right)$ and the quantity of biodegraded carbon (Fig. 4). The biodegradation efficiency calculated using the $\mathrm{CO}_{2}$ data refers to the complete transformation of the hydrocarbons to $\mathrm{CO}_{2}$ (mineralization). If hydrocarbons are partially biodegraded, the quantification of $\mathrm{CO}_{2}$ does not take into account these incomplete processes.

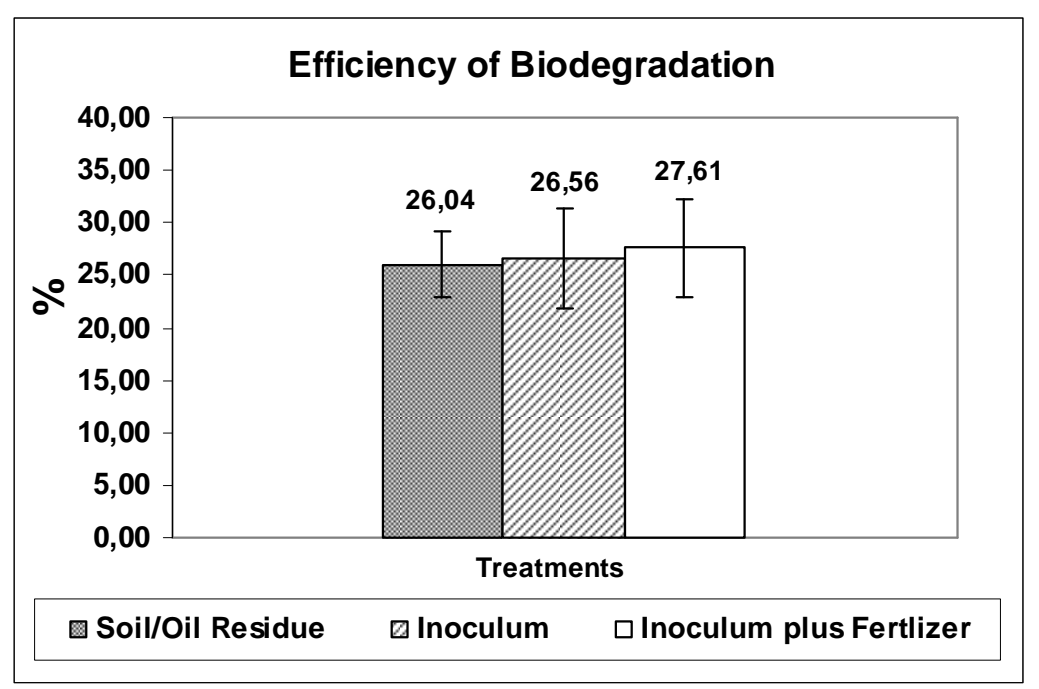

Figure 4 - Efficiency of biodegradation according to initial carbon levels in the soil and quantity of carbon biodegraded.

The addition of inoculum, and of inoculum plus fertilizer, increased the efficiency of the oil residue biodegradation by 0.52 and $1.57 \%$, respectively, compared to the efficiency of the soil/oil residue control. The statistical test of variance $(\mathrm{F}=$ 0.1074; $\mathrm{p}=0.8992)$, however, showed no significant differences in the values $(p>0.05)$. Thus, the addition of inoculum, and of inoculum plus fertilizer, did not effectively contribute to the increase in efficiency of biodegradation.

Due to the presence of petroleum hydrocarbons in the landfarming area where the microorganisms used in the inoculum were isolated, it was thought that they would be better adapted to these compounds and more effective in degrading them. The inefficiency of the use of the inoculum 
observed in this study could be related to various environmental factors in the process of biodegradation. In addition, following the isolation of the microorganisms from the landfarming, they were stored and later activated in culture media appropriate for growth, perhaps inducing a loss in their capacity to biodegrade and use the hydrocarbons.

The nutritional content of the medium in which biodegradation of dangerous substances is to be undertaken should include a good balance between carbon, phosphorous, and nitrogen for the development of the microorganisms (Atlas, 1995; Gallego et al., 2001; Gogoi et al., 2003). The findings suggested that the addition of fertilizer could accelerate the biodegradation of oil residues from petroleum, although the concentration used does not appear to have been appropriate and could be re-adapted using the same methodology. Techniques involving the measurement of $\mathrm{CO}_{2}$ during the biodegradation of dangerous substances have proven useful for establishing protocols for the treatment of industrial wastes and even in programs to recuperate impacted areas, saving time and financial resources.

\section{CONCLUSIONS}

In this study, the use of mixed-culture inoculum and nutrients did not contribute to an increase in the rate of biodegradation of the residue studied. New studies should be developed, however, to optimize the rate of biodegradation of the same residue studied here. It is suggested that microbial strains isolated from environments impacted by dangerous substances should be stored in laboratory conditions very similar to the environments from which they were isolated. This should be done to maintain their existing characteristics and prevent the loss of metabolic activity related to biodegradation. The use of nutrients in commercial form (NPK) may provide economic advantages during the biodegradation of oil residues, although the ideal concentrations must be established.

\section{ACKNOWLEDGEMENTS}

This study was financed by the Fundação de Amparo à Pesquisa do Estado de São Paulo (FAPESP). The authors would also like to thank REPLAN (Paulínia Refinery) for providing the oil sludge.

\section{RESUMO}

Neste estudo foi investigado o potencial de um inóculo composto de cultura mista de bactérias e fungos, isolados do landfarming da Refinaria de Paulínia, Brasil, em degradar resíduos oleosos gerados no processo de refinamento de petróleo. $\mathrm{O}$ isolamento desses microrganismos foi realizado previamente, supondo-se que estejam melhor adaptados aos hidrocarbonetos de petróleo uma vez que o landfarming consiste em área impactada por deposição de tais compostos. Utilizou-se o teste respirométrico de Bartha e Pramer no intuito de verificar a taxa de biodegradação dos hidrocarbonetos pela cultura mista de microrganismos através da evolução de $\mathrm{CO}_{2}$. Os resultados obtidos para a eficiência da biodegradação não apresentaram diferença estatisticamente significativa $(\mathrm{P}>0.05)$ indicando que não houve aumento do processo de biodegradação com o uso do inóculo. A adição de nutrientes $(\mathrm{N}, \mathrm{P}, \mathrm{K})$ tampouco contribuiu para aumentar a biodegradação do resíduo oleoso estudado.

\section{REFERENCES}

Atlas, R. M. (1992), Oil spills: regulation and biotechnology: guest editorial. Curr. Opin. Biotechnol., 3 (3), 220-223.

Atlas, R. M. (1995), Petroleum biodegradation and oil spill bioremediation. Mar. Pollut. Bull., 31, 178-182.

Ayotamuno, M. J.; Kogbara, R. B.; Ogaji, S. O. T.; Probert, S. D. (2006), Bioremediation of crude-oil polluted agricultural-soil at Port Harcourt, Nigeria. Appl. Ener., 83, 1249-1257. 
Balba, M. T.; Al-Awadhi, N.; Al-Daher, R. (1998), Bioremediation of oil-contaminated soil: microbiological methods for feasibility assessment and field evaluation. J. Microbiol. Methods, 32, 155164.

Bier, O. (1994), Microbiologia e Imunologia. Melhoramentos, São Paulo.

Capelli, S. M.; Busalmen, J. P.; Sánchez, S. R. (2001), Hydrocarbon bioremediation of mineral-base contaminated waste from crude oil extraction by indigenous bacteria. Int. Biodeterior. Biodegrad., 47, 233-238.

Cetesb. Companhia de Tecnologia e Saneamento Ambiental (1984), Norma Técnica L. 6.245: solos coleta e preparação de amostras - procedimentos. São Paulo: CETESB.

Cetesb. Companhia de Tecnologia e Saneamento Ambiental (1990), Norma Técnica L. 6.350: solos determinação da biodegradação de resíduos - método respirométrico de Bartha. São Paulo: CETESB. 15pp.

Chaerun, S. K.; Tazaki, K.; Asada, R.; Kogure, K. (2004), Bioremediation of coastal areas 5 years after Nakhodka oil spill in the Sea of Japan: isolation and characterization of hydrocarbon-degrading bacteria. Environ. Int., 30, 911-922.

Chaillan, F.; Le Flèche, A.; Bury, E.; Phantavong, Y.; Grimont, P.; Saliot, A.; Oudot, J. (2004), Identification and biodegradation potential of tropical aerobic hydrocarbon-degrading microorganisms. Res. Microbiol., 155, 587-595.

Chaîneau, C. H.; Morel, J.; Dupont, J.; Bury, E.; Oudot, J. (1999), Comparison of the fuel oil biodegradation potential of hydrocarbon-assimilating microorganisms isolated from a temperate agricultural soil. Sci. Total Environ., 227, 237-247.

Del' Arco, J. P.; França, F. P. (2001), Influence of oil contamination levels on hydrocarbon biodegradation in sandy sediment. Environ. Int., 110, 515-519.

Gallego, J. L. R.; Loredo, J.; Llamas, J. F.; Vázquez, F.; Sánchez, J. (2001), Bioremediation of dieselcontaminated soils: evaluation of potential in situ techniques by study of bacterial degradation. Biodegradation, 12, 325-335.

Genow, G.; Naeyer, F.; Van Meenen, P.; Van de Werf, H.; Nijs, W.; Verstraete, W. (1994), Degradation of oil sludge by landfarming - a case-study at the Ghent harbour. Biodegradation, 5, 37-46.

Gogoi, B. K., Dutta, N. N., Goswami, P., Mohan, T. R. K. (2003), A case study of bioremediation of petroleum-hydrocarbon contaminated soil at crude oil spill site. Advances Environ. Res., 7, 767-782.
Jørgensen, K. S.; Puustinem, J.; Suortti, A. M. (2000), Bioremediation of petroleum hydrocarboncontaminated soil by composting in biopiles. Environ. Int., 107, 245-254.

Kataoka, A. P. A. G. (2001), Biodegradação de resíduos oleosos de refinaria de petróleo por microrganismos isolados de "landfarming". $\mathrm{PhD}$ Thesis, Universidade Estadual Paulista, Rio Claro.

Li, G.; Huang, D. N.; Lerner, D. N.; Zhang, X. (2000), Enrichment of degrading microbes and bioremediation of petrochemical contaminants in polluted soil. Water Res., 34 (15), 3845-3853.

Margensin, R.; Zimmerbauer, A.; Schiner, F. (2000) Monitoring of bioremediation by soil biological activities. Chemosphere, 40, 339-346.

Miranda, R. C; Souza, C. S.; Gomes, E. B.; Lovaglio, R. B.; Lopes, C. E.; Souza, M. F. V. Q. (2007), Biodegradation of diesel oil by yeast from the vicinity of Suape Port in the State of Pernambuco - Brazil. Braz. Arch. Biol. Tecnol., 50 (1), 147-152.

Mrayyan, B.; Battikhi, M. N. (2005), Biodegradation of total organic carbons (TOC) in Jordanian petroleum sludge. J. Hazard. Mater., 120, 127-137.

Nocentini, M. Pinelli, D. Fava, F. (2000), Bioremediation of a soil contaminated by hydrocarbon mixture: the residual concentration problem. Chemosphere, 41, 1115-1123.

Régis, G.; Bidoia, E. D. (2005), Electrolytic treatment applied to the industrial effluent containing persistent wastes monitored by Bartha Respirometric assays. Braz. Arch. Biol. Tecnol., 48 (2), 319-325.

Rosato, Y. B. (1997), Biodegradação do petróleo. In: Melo, I. S.; Azevedo, J. L. Microbiologia Ambiental. Embrapa, São Paulo. pp. 307-304.

Ururahy, A. F. P.; Marins, M. D. M.; Vital, R. L.; Gabardo, I. T. Pereira Jr, N. (1998), Effect of aeration on biodegradation of petroleum waste. Rev. Microbiol., 29, 254-258.

Vasudevan, N.; Rajaram, P. (2001), Bioremediation of oil sludge-contaminated soil. Environ. Int., 26, 409411.

Yoshida, N.; Yagi, K.; Sato, D.; Watanabe, N.; Kuroishi, T.; Nishimoto, K.; Yanagida, A.; Katsuragi, T.; Kanagawa, T.; Kurane, R.; Tani, Y. (2006), Bacterial communities in petroleum oil in stockpiles. J. Biosc. Bioeng. 99 (2), 143-149.

Received: March 08, 2007; Revised: February 07, 2008; Accepted: March 27, 2009. 